Article

\title{
Partnerships for Private Transit Investment-The History and Practice of Private Transit Infrastructure with a Case Study in Perth, Australia
}

\author{
Sebastian Davies-Slate and Peter Newman * (ID \\ Curtin University Sustainability Policy Institute, GPO Box U1987, Perth, WA 6845, Australia; \\ sebastian.davies-slate@curtin.edu.au \\ * Correspondence: p.newman@curtin.edu.au; Tel.: +61-426-677-944
}

Received: 25 July 2018; Accepted: 28 August 2018; Published: 3 September 2018

\begin{abstract}
Urban transit planning is going through a transition to greater private investment in many parts of the world and is now on the agenda in Australia. After showing examples of private investment in transit globally, the paper focuses on historical case studies of private rail investment in Western Australia. These case studies mirror the historical experience in rapidly growing railway cities in Europe, North America, and Asia (particularly Japan), and also the land grant railways that facilitated settlement in North America. The Western Australian experience is noteworthy for the small but rapidly growing populations of the settlements involved, suggesting that growth, rather than size, is the key to successfully raising funding for railways through land development. The paper shows through the history of transport, with particular reference to Perth, that the practice of private infrastructure provision can provide lessons for how to enable this again. It suggests that new partnerships with private transport investment as set out in the Federal Government City Deal process, should create many more opportunities to improve the future of cities through once again integrating transit, land development, and private finance.
\end{abstract}

Keywords: entrepreneur rail model; value capture; city deals; private railways; Western Australia; tramways; streetcars; land grants; future cities; urban planning

\section{Introduction}

After decades of strong government control of urban public transport infrastructure, transit planning is going through a transition to greater private investment in many parts of the world [1]. This is based on demand for a rapid transit system that can overcome traffic problems [2]. The process for doing this through private investment is obviously one that requires a partnership between all levels of government and the private sector and these are increasingly being labelled 'city deals' $[3,4]$. The focus on bringing private investment into transit funding is now on the agenda in Australia as it is required by city deals from the federal government $[5,6]$.

This paper sets out to show how this global process is happening, how it could indeed follow the historical process that first set up transit systems using private investment, and how historical case studies from Western Australia suggest two means to enable the new transition. Examination of these new case studies adds to the global body of evidence of the entrepreneur rail model [1] and provides some insight into how such models might be reintroduced. It concludes by suggesting that the city deal governance process may be able to mimic the historic integration of transit, land development, and private finance so eagerly sought after by cities. 


\subsection{New Investment in Urban Transit}

Rail transport is going through a renaissance globally, in what [6] calls "the Second Rail Age", with a concomitant peak and then decline in car use per capita [7]. This rail revival has involved new rail investment in the dense cities of Europe, the Middle East, and Asia, but also in the more car-dependent cities of the United States, Canada, and Australia [2]. The reason for this renaissance is the demand for better accessibility in cities where traffic speeds are no longer competitive with fast transit that can go under, over, or around the traffic [2]. Cities are now having to respond to this increasing demand by trying to find alternative funding sources and private participation, with a number of new models emerging.

In southern Florida, the Brightline, a privately funded and financed regional railway, recently began operation. This project has drawn substantial funding from transit-oriented developments around its stations (see Figure 1) [8]. This privately delivered model is favoured by the state administration, as a means to deliver infrastructure without a financial burden or financial risk to the public sector. In announcing a Brightline extension between Tampa and Orlando, the Governor of Florida stated that "through private investment, we ensure that this major project has zero financial risk to Florida taxpayers", comparing this model with the California High-Speed Rail project, which was federally funded. The Florida Department of Transportation is to run an open procurement process for the right to lease government-owned land along the corridor, rather than offering any funding support [9].

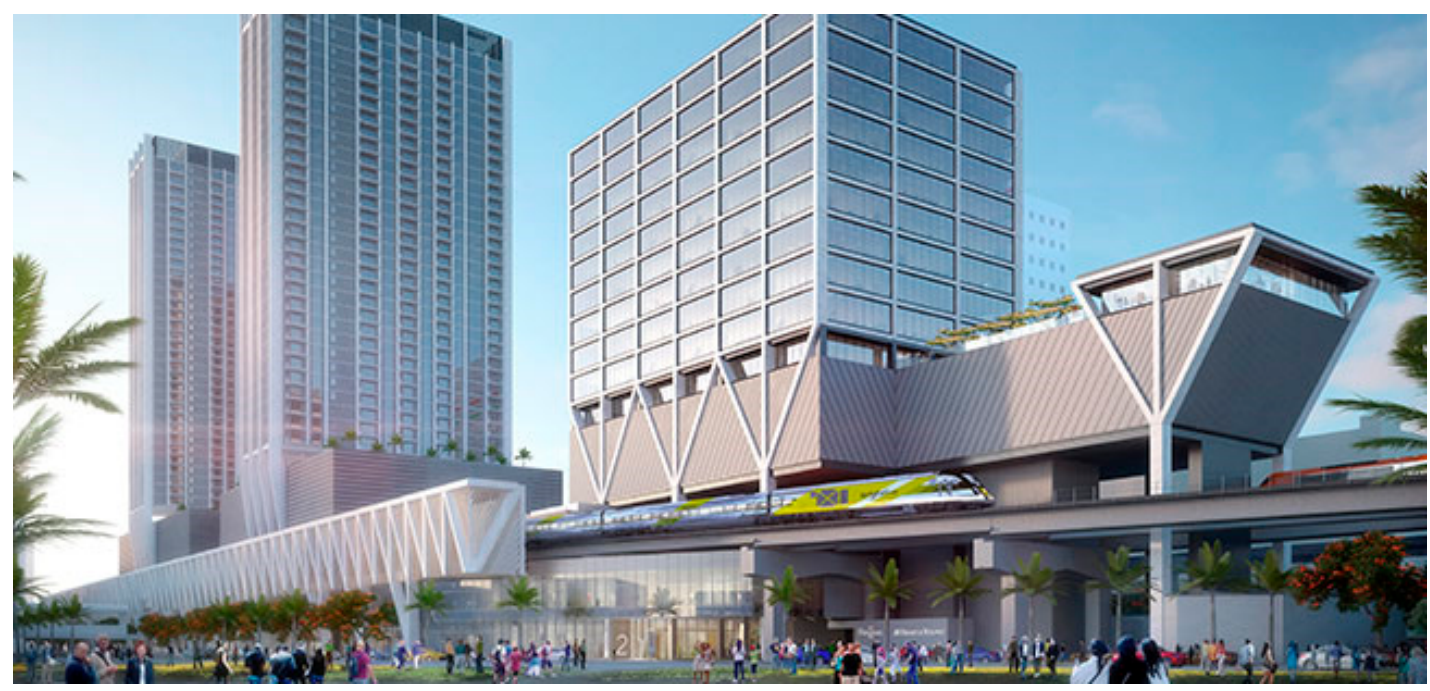

Figure 1. Miami Brightline. Source: All Aboard Florida, Brightline.

In Montreal, the provincial pension fund-the Caisse de dépôt et placement du Québec-is developing an elevated light rail line, with substantial funding from its depositors. The Caisse sees this as an opportunity for a long-term investment in "tangible assets that generate stable, predictable returns", in addition to delivering a public good outcome [10].

In Australia, the Consolidated Land and Rail Australia (CLARA) group is planning a high-speed rail line between Sydney and Melbourne, building new cities along the route. This new development will be used to service the project's finance. This project was a private initiative, but was undertaken in response to a long-running policy objective, which conventional public funding models had not been able to deliver [11].

In London, the $£ 14.8$ billion Crossrail project has sourced funding from a variety of sources, including the Greater London Authority, Department for Transport, and the private sector [12]. The UK Government's contribution had been capped at one-third of the total cost, so alternative sources of funding were required for the project to proceed [13]. 
Private funding is not that unusual in transport as toll roads are a common form of alternative funding; Regan et al. identify eight toll road projects implemented since 2003 in Australia alone [14]. Several of these have failed financially - the Cross City Tunnel, Lane Cove Tunnel, Clem 7 Tunnel, and the Brisbane Airport Road Tunnel failing to live up to their forecast traffic volumes [15]. However, railway capital funding has not been easily able to achieve sufficient return just from tolls (fares). The new approach has been a rediscovery of the insight that funding for rail is more likely to be raised from the increase in land values. The mechanisms for doing this have been found to vary across the globe either through various forms of additional levies or taxes [16-20], business improvement districts or special improvement districts [20-22] or transit-oriented development by the rail provider. The latter can involve joint development, in which a public transit agency's land assets are leased to a private partner [23-25] or more privately-led initiatives, such as the Japanese railway conglomerates, or London's Metropolitan Railway [26].

This paper considers how private funding of rail projects has happened in history and could be reintroduced into contemporary cities. Australia is somewhat lagging in developing more entrepreneurial rail building models compared with other parts of the world, but this paper shows there are historical models of railway development which were previously not well documented and which could help inform a future model of entrepreneurial rail-building in Australian cities. These case studies add to the literature on privately developed railways, integrated with land development, and provide further evidence of the effectiveness of this model.

Infrastructure planning and delivery in Western Australia is not averse to private investment, except in urban transport, both in roads and public transport. Perth Airport is run by a private company financed mostly by superannuation funds, including being $30 \%$ owned by a subsidiary of the Australian Government's Future Fund [27]. The mining community are structured to provide their own rail and road systems without government investment, including railways and roads. The government instead performs a regulatory function, through regulating third party access to railways and rail safety. There also is increasing involvement of private investment in health and education. However, in urban areas, including the capital city, there is no private investment in transport, just private involvement in the construction of the road and rail systems under government supervision. This is being challenged by the federal government's new involvement in Australian cities through city deals.

\subsection{Land Value Uplift and the Entrepreneur Rail Model}

Railway operations have often been difficult to make profitable through fare revenue alone [28-30], and there have been many attempts to address this deficit by taking advantage of the effect of railways on the value of surrounding land.

The land value effects of railways have been estimated by numerous prior studies. The common method of undertaking these estimates is hedonic price modelling, which estimates the willingness to pay for certain features of a property [31], such as its proximity to schools, parks, or in this case railways. The body of empirical evidence for the effects of the presence of railways on land values is substantial, with useful summaries of this research published [30,32].

Many forms of value capture have been documented. These include compulsory land-based levies, such as the "impact fee" in the United States [18], increments on property rates paid by business [15], special area levies [18]; tax increment financing [20,32], special improvement districts [20,21,33], and various forms of joint development programs [25,30].

The mechanisms listed above involve additional revenue being raised from land to fund infrastructure delivery by government agencies. In addition to these public funding models, there is a substantial amount of rail building by private companies and commercially-motivated government-owned businesses that we have called the entrepreneur rail model [1]. These invariably make use of land assets to increase their profitability. The Hong Kong MTR Corporation is well documented [24] and the Japanese railway companies have been particularly adept at finding alternative sources of revenue, with real estate development and management being particularly significant [34]. 
As will be shown below, this entrepreneur rail model was practiced in many parts of the world in earlier times and it is the purpose of this paper to see what can be learned from this as cities across the world look to build a lot more urban rail.

\subsection{Theory, Purpose, and Structure of the Paper}

This paper is part of two urban science theories: the theory of sustainable cities and urban fabric theory. The first, developed by [35], suggests that cities become more sustainable when they reduce their metabolism (resource consumption and waste production) whilst simultaneously improving their livability (economic and social factors like jobs, health and community). The theory shows how this cannot be done without restructuring the city and this primarily is determined by transport priorities. The second theory [36] pursues this concept in more detail by showing that every city has a combination of three cities, based on their history of development: walking city, transit city, and automobile city. The three eras are based on transport priorities and create three different fabrics: walking fabric, transit fabric, and automobile fabric. The relevance to this paper is that global priorities have shifted to seeing the significant economic, social, and environmental benefits of having more walking and transit fabric; this cannot happen unless cities find new ways of restoring the transport priorities and investment in these modes whilst at the same time building in their associated urban fabrics. Thus, the urban science of transport and land use planning needs to understand the history of transport and how to learn from it in delivering more sustainable cities.

The paper brings new case studies to the global body of evidence on the entrepreneur rail model, in the form of urban tramways (as streetcars are referred to in Australia) and land grant railways in late-19th and early-20th Century Western Australia. It examines the regulatory regimes prevailing at the time of these projects, offering potential guidance to future policy makers.

These case studies are notable for the small and isolated settlements involved. The paper also discusses the urban contexts in which these projects took place, noting the rapid population growth during the time of the streetcars. There is extensive literature on the viability of transit in terms of urban density, but the rate of population growth will also be a relevant variable for entrepreneur rail model projects (see discussion below).

The remainder of this paper is set out as follows:

- Section 2 provides a series of global historical case studies of entrepreneurial rail building. Rather than being a comprehensive history this is intended to demonstrate the breadth of this model of railway building - commercially-motivated and linked to land development.

- Section 3 examines the Western Australian case studies, being Perth Electric Tramways Ltd. and the earlier land grant railways.

- Section 4 draws conclusions on the potential for this model of railway building to be revived in contemporary western cities, potentially incorporating the more recent governance innovation of the city deal.

- Section 5 contains concluding remarks.

\section{Global Entrepreneurial Rail History}

Linking land development with railways is almost as old as the technology itself. A brief overview of railway history in Britain, North America, and Asia will set the scene before further pursuing the Australian and Perth rail stories.

\subsection{Britain}

In Britain, a period of rapid railway expansion took place during the 1840s, after several technological developments during the 1830s and 1840s. This peaked in a speculative frenzy called the "Railway Mania" [37]. This ended in a crash in the late 1840s and early 1850s, with a sharp decline in revenue per mile of track. There have been widespread suggestions of accounting fraud during this 
period, although hard evidence for this is limited, and overly optimistic predictions or obfuscations regarding construction cost and revenue are more substantiated [38]. However, the resultant spread of railways around the country resulted in exponential growth in passenger numbers over the following decades (see Figure 2) followed by a downturn in the 20th century, until its recent privatization which has taken rail into a new period of substantial growth. It has been suggested that the losses associated with the Railway Mania were exacerbated by inefficiency in the route planning of the early railways, based on the assumptions of proponents that their business would be dominated by travel between major cities, rather than taking account of demand in smaller places [39]. With demand now settled and big cities growing, the second rail revolution is now well underway.

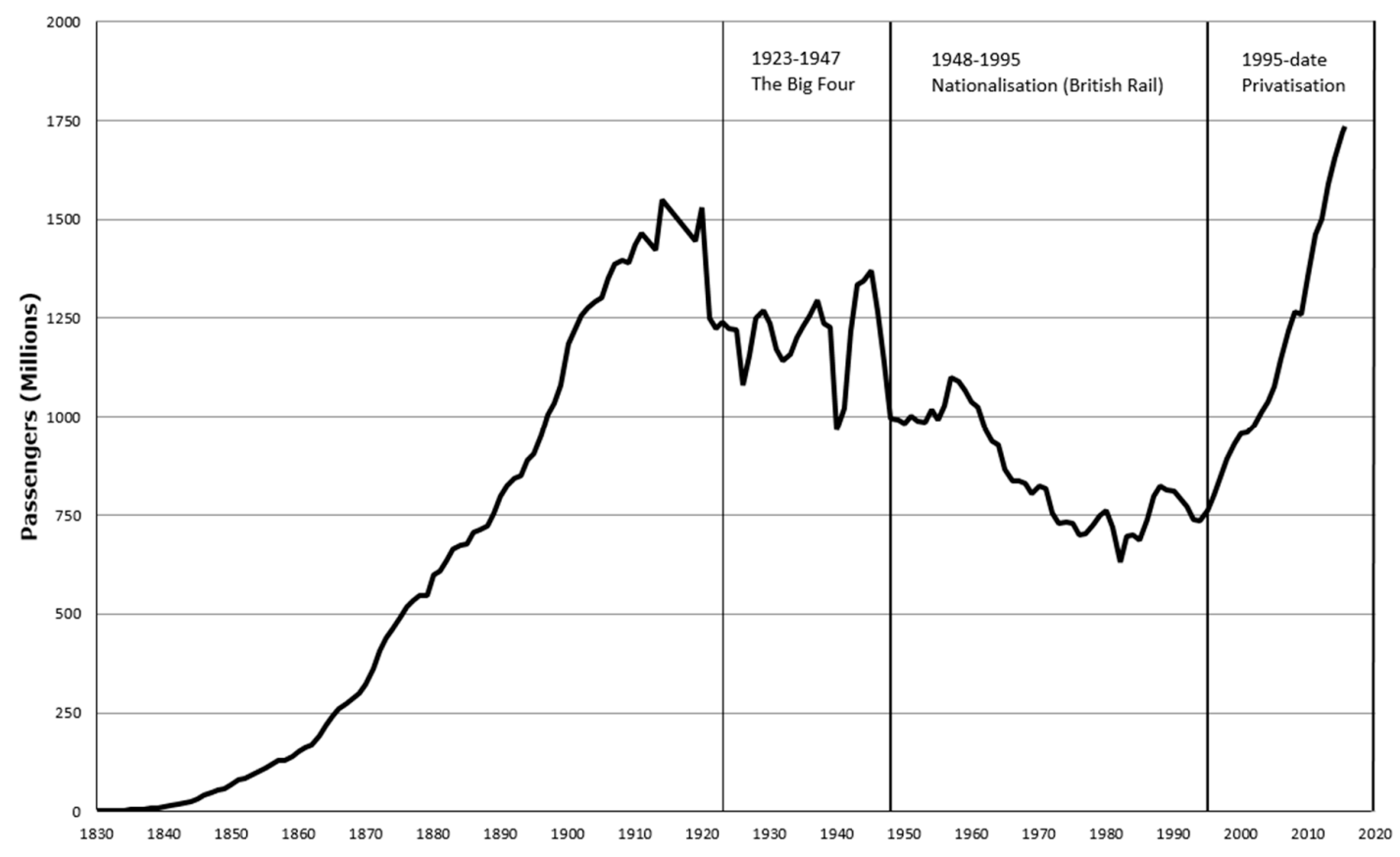

Figure 2. Railway passenger numbers in the U.K., 1829-2016. Source: Wikipedia Commons.

The effects of railways on real estate was quickly realised in the 19th century and was particularly prominent in development of the London Underground with much of what became the London Underground being built as joint railway and suburban development projects.

The Metropolitan Railway began as a public-private partnership, with the City of London purchasing $£ 200,000$ worth of shares in the company and the company concurrently purchasing land of $£ 179,000$. A railway was opened in 1863 , built with these funds, and with high ridership. Over time, the company consolidated several other railway companies as well as acquiring bus and tram operators and integrated these services with its railway business [40]. As shown above the first signs of a return to greater private investment in UK rail is now beginning.

\subsection{North America}

In the United States, land grant railways were used as a means to settle and develop the interior and west of the country, and link the two coasts by rail. The US Federal Government operated a land grant system between 1855 and 1871, giving millions of acres of land in the west to railway companies. Private railway companies built an extensive network across the country, providing access to farms and connecting cities [41]. There was a period of reorganisation of the industry, with J.P. Morgan, a New York financier, playing a prominent role. He both raised funds in Europe, and helped the railway companies reorganise and thereby operate more efficiently.

In addition to long distance railways enabled with federal land grants, streetcars were introduced into many American cities by private operators, expanding them beyond the range of the old walking 
city. Warner gives a detailed account of the development of Boston from around 1850 onwards, during which streetcars were introduced, initially horse-drawn, and the metropolis expanded from the core walking city of approximately two and a half miles in radius [42]. These streetcars were often built as a device for marketing land on the outskirts of the old walking-based city [36].

In Canada, the Canadian Pacific Railway was built in the early 1880s to link the then populated eastern part of the country with the under-developed west. Challenging terrain and the great distances involved almost bankrupted the Canadian Pacific Railway Company, but the line was ultimately completed in 1885 .

The company was involved in a range of related businesses, including land sales and settlement. This began in 1881, before construction was even complete [43]. The Canadian Government had granted the company 25 million acres $\left(100,000 \mathrm{~km}^{2}\right)$ of land, and it was sold on to settlers, whom it actively recruited [44]. The company campaigned to attract settlers to the area, advertising in various countries. The settlers were often sold a package that included the land, sometimes ready-made farms, and transport by the company. Under this railway-led immigration scheme, the population of Canada increased by one-third in the first decade of the 20th Century, from 5.3 million people to 7.2 million people [45].

Canadian Pacific is still in operation, and offers land along its network for lease [46]. With the advent of the motor car and bus, the era of railway development went into hiatus, but investment in rail has increased in recent years, in the Second Rail Revolution [4] though it is only very isolated compared to the historic era of rail growth.

\subsection{Asia}

While the practice of entrepreneurial rail building mostly ended in Europe and America during the period after the first half of the 20th Century, several Asian countries have continued the practice in developing their rapidly-expanding cities. In Japan, the railway network is a complex mix of public, private, and privatised railways. Several companies have used railways to enable new town developments on the outskirts of the major cities, with a large number of lines branching off the Yamanote Line to the west of Tokyo, and a number of such lines having been built in the Kansai region. This model was pioneered in the early 20th Century by the Hankyu Railway Company, Osaka. Hankyu struggled to profit on railway fares alone, and so began building housing estates and later office towers along their railways.

The land into which Tokyu expanded was often broken up into a large number of farming lots, creating a complication for land assembly. The solution that evolved to deal with this issue is known as land readjustment. Under this model, land owners would contribute their land to the development project, and in return would receive back a smaller portion of improved land, with services installed and a new railway connection. The original land owners were also placed on a committee that oversaw the urban design outcomes that occurred as part of the new developments. Interestingly, one of the pioneering companies was Tokyu Corporation, originally a town planning firm, and whose founder was inspired by Ebenezer Howard's vision of a series of garden cities for the working population. It was Tokyu's reputation as an ethical business that enabled it to gain the trust of the farmers when seeking to redevelop their land [34].

In Hong Kong, the Mass Transit Railway Corporation (MTR) is a semi-public, semi-private organisation listed on the Hong Kong Stock Exchange, but majority owned by the government [39]. The MTR receives land from the Hong Kong Government at pre-rail prices, and then builds the railway infrastructure and develops the land in partnership with private developers. This model is known as 'rail + property'. Property rental and management is a large part of the MTR's business, accounting for more of the company's operating profits than its heavily-patronized transport operations [47]. Property-related businesses operating in Hong Kong accounted for $57 \%$ of total operating profit on average between 2012 and 2016 (see Figure 3). 


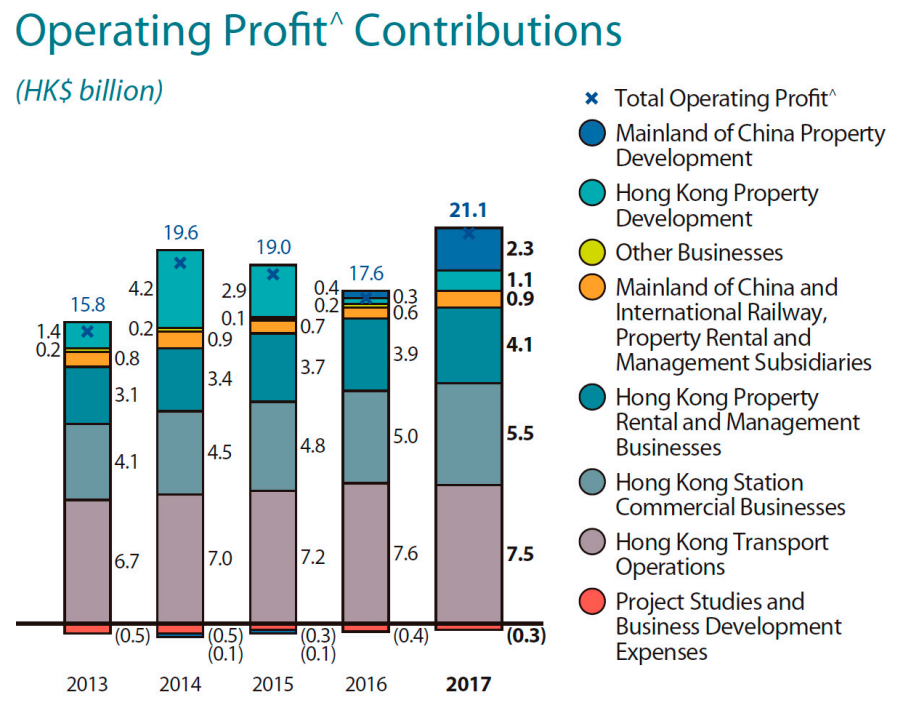

Figure 3. Hong Kong MTR Corporation operating profit. Source: MTR Corporation [48].

In Singapore, transport and land use planning is much more centrally controlled, although there is still considerable private involvement and a core function of returning money to government through land development. The Singapore Government, through the Land Transport Authority (LTA), owns the entire railway network [49], but contracts out operation of different sections of the network to two companies: Singapore MRT (SMRT) and SBS Transit [50]. Bus operations are also contracted out under a contracting model begun in 2016, with the LTA owning all the buses, collecting all the fare revenue, and then leasing the buses to operating companies [51]. SMRT has previously been partly privately-owned, similar to Hong Kong MTRC, but is now $100 \%$ owned by Temasek, the Singapore Government's investment company [52]. Responsibility for planning, designing, and building the network lies with the Land Transport Authority, a statutory authority under the Minister for Transport [53].

Large scale land development is undertaken by two public organisations: The Housing and Development Board and the Urban Redevelopment Authority. They earn revenue from rental payments, car parking, sales, and interest [54]. Land development-related funding is therefore a strong part of the success in Asia's most successful rail systems.

\subsection{Australia}

Rail building in Australia began in the middle of the 19th Century, and was a mix of private and government schemes, depending on the colony. The first railway track in New South Wales began construction in 1849, built by the Sydney Railway Company. This ran for $22 \mathrm{~km}$ between Sydney and Parramatta and opened in 1855. The line was not financially successful and was taken over by the colonial government of New South Wales. In Victoria, the Melbourne and Hobson's Bay Railway Company opened a line between what is now Flinders Street Station and the Port of Melbourne in 1854. In Queensland and South Australia, the respective governments began railway construction in 1864 and 1854 in rural mining areas. In Tasmania, the Launceston and Western Railway Company opened a line between Launceston and Deloraine in 1868 [55]. In Western Australia, the Department of Works and Railways was formed in 1877, and Western Australian Government Railways built the Geraldton to Northampton railway in 1879 for mining-related activity. This was followed by passenger railways connecting Perth to Fremantle and Guildford in 1881 [56].

Western Australia's rail history provides two case studies of entrepreneurial rail building: the privately-built tramway network and the land grant railways running from near Perth, the state capital and principal city, to the regional centres of Albany and Geraldton. 


\section{Historical Case Studies from Western Australia}

Western Australia had a history of entrepreneurial rail building in the late-19th and early-20th centuries, and these historical examples provide some insights into how rail infrastructure might be procured today without resort to public funding.

The case studies presented in this paper are:

- The Perth Electric Tramways Limited, a British company that laid down the core of the extensive tramway network in the capital city, Perth, which was later subject to state takeover.

- The land grant railways-two railways were developed in Western Australia with grants of undeveloped land that the government was unable to bring under development on its own. This model was essentially the same as the American railways and the Canadian Pacific.

All of these lines were funded and financed from private money, with land development as the ultimate source of funding. These privately-funded lines carried both passengers and freight, including building materials to the developments they serviced, and in the case of the tramways, 'night soil', as this was prior to sewerage systems being installed in many parts of the city.

\subsection{Perth Electric Tramways Limited}

Perth once had an extensive tramway network, much of it built by a private company, the Perth Electric Tramways Limited. The system was taken over by the state government in 1913 (Tramways Purchase Act 1912), and progressively closed down in the 1950s and 1960s (pp. 153-161, [57]).

The individual lines were built under a well-established regulatory framework. This involved the tramway company and relevant local authority reaching an agreement on the new route, and then seeking an order from the state government, ending by being ratified by Parliament.

At the time of the state takeover in 1913, the Perth Electric Tramways Limited was running a substantial network, including lines used to enable real estate development on the then urban fringe. This model was strikingly similar to that used by the Japanese railways and was roughly contemporaneous with the establishment of the Hankyu railway company in Osaka. This model's success in Perth is particularly noteworthy given the relatively small size of the settlement at the time, albeit growing very rapidly, from approximately 71,000 people in 1901 to 111,000 people in 1911 [58], an annualised growth rate of $4.7 \%$.

\subsubsection{Tramway Regulatory Framework}

Tramways in Western Australia were built under a regulatory framework laid out in the Tramways Act 1885 [59]. This Act was modelled on the United Kingdom's Tramway Act, and also mirrored the acts in force in the neighbouring colonies (that is, the rest of Australia, and possibly New Zealand) [60].

This act created the regulatory framework for private or municipally-led tramways. A potential private promoter or a local council could apply to the Commissioner of Railways (a political rather than bureaucratic role) for the authority to build a tramway. This authority was known as a provisional order, and the Commissioner had extensive powers to mandate various design and operational standards (for example, track width, track slab material, minimum service frequencies, maximum travel speeds, and others). This provisional order required a further Act of Parliament to come into effect, and was sometimes amended by Parliament.

The Commissioner retained significant powers over the tramway, including the right to vary a section of its alignment, and to force the tramway operator to pay for a bridge over a railway track, if the government decided to build a railway that crossed the tramway in the future.

The government also took a bond from the promoter, as a guarantee that work would progress, and there were tight construction timelines included in the provisional orders, within which construction was required to be commenced and completed.

There were protections for the local communities from tramway development, with consent generally required by local authorities, and tramways were not to be built within 10 feet of the foot 
path, if one-third of the property owners abutting this section dissented. These protections would have required significant negotiation by the promoter with local stakeholders, which is also a feature of Japanese railways and the associated land assembly and redevelopment.

The first tramway was opened in 1899 [57]. Well-preserved records survive for two integrated tramway and real estate developments: the Nedlands Park and Osborne Park tramway estates.

\subsubsection{Nedlands Park Tramway Estate}

As noted above, streetcars were privately developed in many American cities, and this process became closely linked with real estate development. The beginnings of a similar process also occurred in Perth, with the Nedlands Park Tramway Estate the most prominent example.

The Nedlands Park Tramway Estate was built on approximately 240 acres of land, which was subdivided into 800 lots [61]. The site was on the boundary of two municipalities, and there was a complicated arrangement with the two local authorities in question. The terms included the following:

- The two authorities would receive 3\% of the gross profits of the tramway operation between them, in lieu of rates payments and in return for the right to use the roadway.

- The developers were to build a public jetty on the river foreshore at the end of the tramway, as well as public baths. The jetty was to be handed over to the one of these municipalities, who would also have the option to purchase the baths at any time. The baths were to be ceded to the municipality at the end of three years regardless.

- A substantial area of river foreshore land was ceded to the two authorities, to be maintained in perpetuity as a reserve for the local community (this foreshore reserve was used as a selling point in marketing the estate).

- The two authorities had responsibility for building and maintaining various roads, and maintaining the foreshore.

While the development obviously was expected to be profitable for the promoter, there was also a benefit to the public finances due to an increased property tax base. The Claremont Roads Board strongly favoured the development and estimated that it would increase their property rates revenue in the area due to raised land values and an increase in building activity (p. 974, [62]). Although the agreement granted considerable concessions to the local authorities, they spent a substantial sum on works in the area, particularly on upgrades to the foreshore.

The proposal was politically contentious, with the opposition party claiming the line should not be built by private enterprise. The reasons given for opposing the plan were that the revenue should be retained by government, if the tramway was profitable, and also that a private tramway should not be allowed to compete with the government railway. The record of parliamentary debates also shows there was concern that the promoters would gain the right to build a tramway as a means to sell the land and then not proceed with construction (p. 1700, [62]).

The Nedlands Park Tramway Act 1907 was passed despite opposition, with a number of conditions imposed on the promoters, including:

- Construction on the tramway was to commence within nine months of the bill being passed, and to be completed within nine months.

- There was to be a minimum service level of nine cars per direction per day.

- Maximum fare levels were set.

- There were certain construction standards, including the materials used and gauge of the tracks-which were the same as on the existing tramway network, $3^{\prime} 6^{\prime \prime}$.

- The promoter was required to pay a deposit of $£ 1000$ into the Colonial Treasury, a substantial sum at the time. If the promoter did not meet minimum service levels over the course of the following 10 years, or failed to complete the tramway on time, then this deposit would be forfeited [63]. 
The tramway was completed in 1908, shortly followed by the public baths and hotel. These facilities were all advertised in the estate's promotional material (see Figure 4). Similar to the department stores and amusement parks built along the Japanese private railways, these facilities were intended to draw visitors to the leisure area at the end of the line, while also acting as an advertisement to potential buyers of the land. These attractions at the end of the tram line would also have generated additional patronage, beyond that of the workers commuting to the central city.

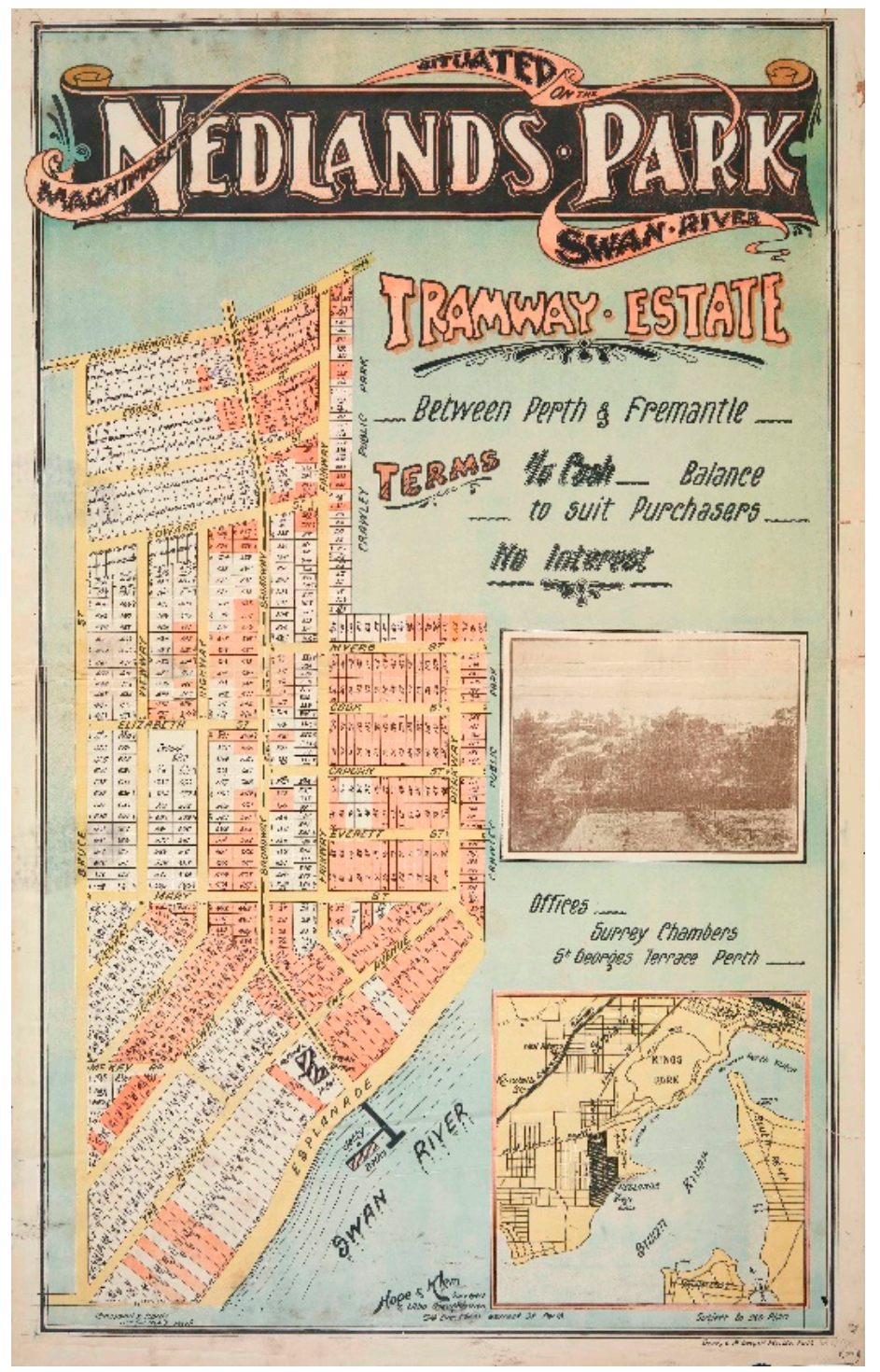

Figure 4. Nedlands Park Tramway Estate map. Source: Battye Library.

\subsubsection{The Osborne Park Development}

The Osborne Park line was built by Town Properties of West Australia Ltd., to promote sales of their 7000-acre land holdings on the northern outskirts of Perth (see Figure 5) [64]. This was prompted by the company having had difficulty selling its lots as they were felt to be too isolated from the city [65]. The company gained authority to build the line through the North Perth and Perth Road Board Districts Tramways Act 1902 [66].

The line was an extension, running from the end of a line in an existing tramway suburb, and terminating outside a hotel and tavern built by the company (p. 47, [67]). This totaled 2.5 miles of new track $(4 \mathrm{~km})$. 


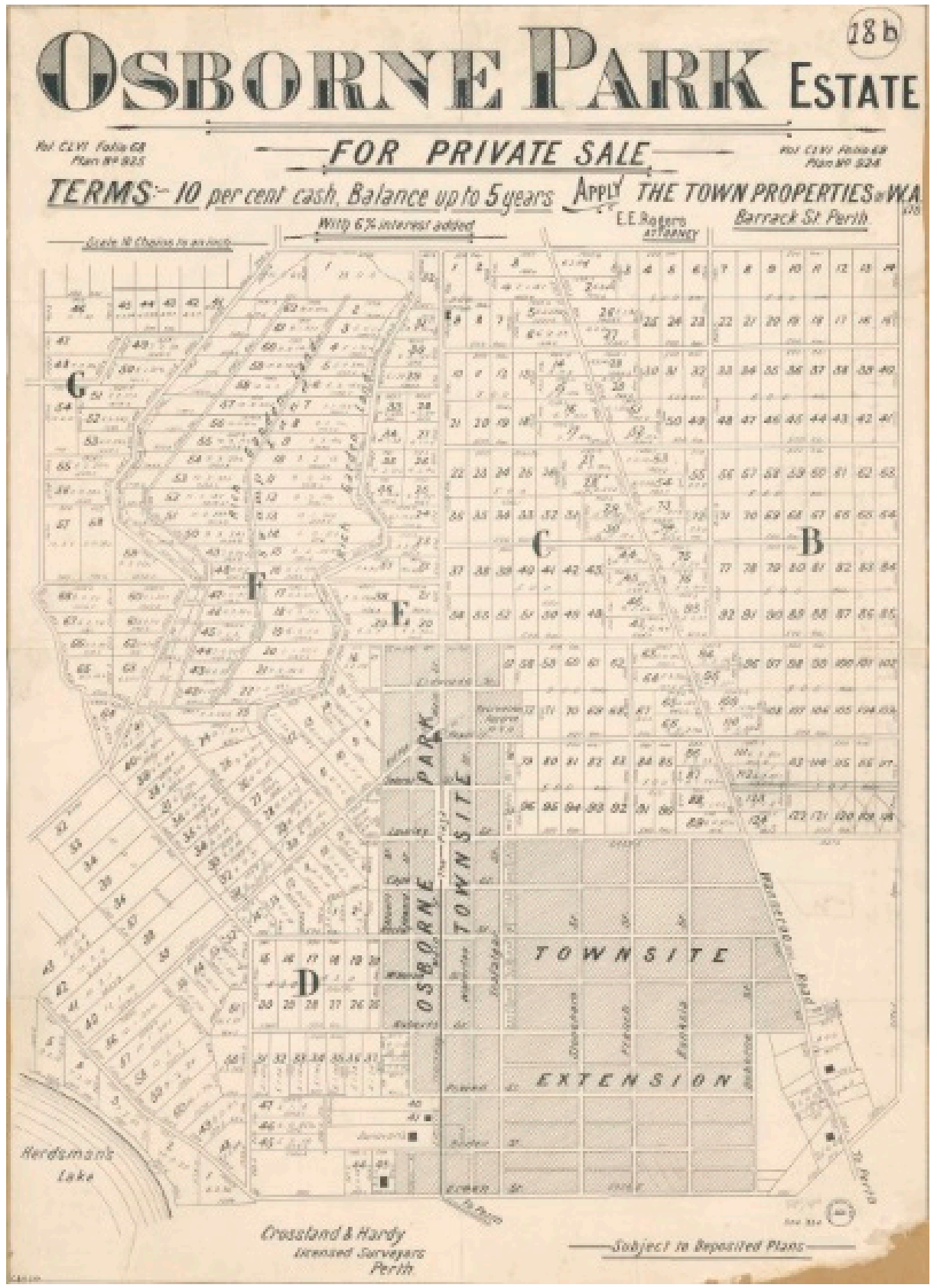

Figure 5. Osborne Park Estate Map. Source: Battye Library.

As was usual for tramway legislation in Western Australia, the local authority had options to purchase the tramway, in the case of the Osborne Park line, after 21 years from the date that the company was required to have completed construction under the act. If this option was not exercised, another option was available after 28 years, and after 35 years the line would have reverted to the local authority anyway, free of charge.

\subsection{Great Southern and Midland Land Grant Railways}

Similar to the United States and Canada, government land grants were provided to a private railway company in Western Australia, to promote government strategic objectives. In the case of Western Australia, there were two objectives: to open up undeveloped land for agriculture and town-building, and to connect Perth with a deep-water port in the town of Albany, over $400 \mathrm{~km}$ away. 
One of these railways, the Great Southern Railway, connected Perth and Albany, while a second land grant railway, the Midland Railway, connected Perth to the port town of Geraldton, a similar distance to the north (see Figure 6).

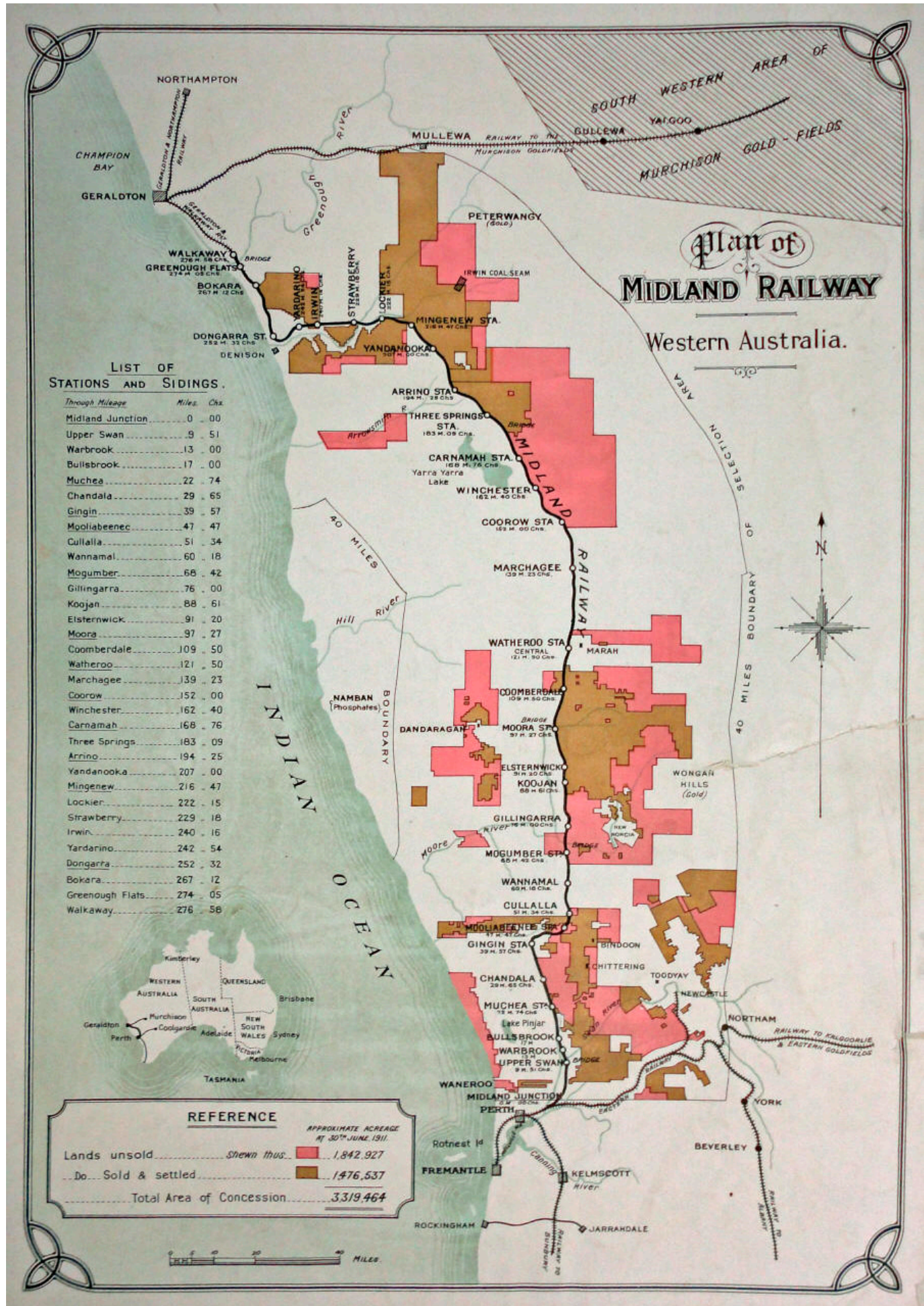

Figure 6. Map of Midland Railway, Western Australia. Source: Carnamah Historical Society.

Under the land grant system, the colonial government granted the companies 12,000 acres of crown land for every mile of track constructed (approximately 3000 hectares per $\mathrm{km}$ ). This land was 
undeveloped, and the companies sold the land on in small parcels as town site lots, as undeveloped parcels, and as ready-made farms, the latter being particularly prevalent on the Midland Railway. The Great Southern Railway resulted from an agreement between the Governor and the West Australian Land Company in 1884, and the Midland Railway in 1886 [68].

This system addressed two issues facing the government at that time: the desire to develop the colony and expand its population, but with the railways being beyond the Government's limited financial means at the time (p. 933, [62]). The land grant system achieved both of these goals, with the companies both raising private capital in London, and advertising the land to potential immigrants across the British Empire (see Figure 7). The companies also provided finance to their purchasers.

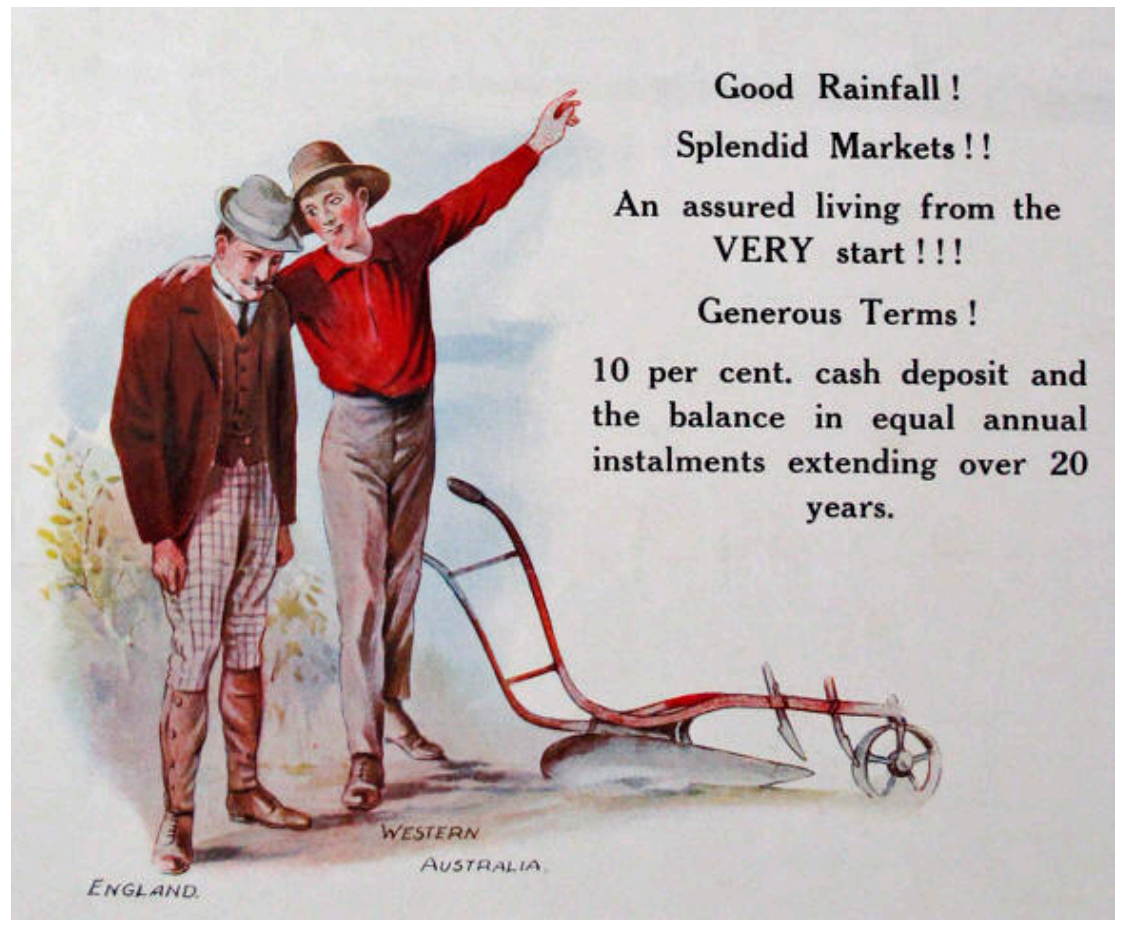

Figure 7. Midland Railway advertisement for farmland. Source: Carnamah Historical Society.

The Midland Railway Company remained in private operation until the 1960s, but the Great Southern Line was taken over by the State in 1896, only 12 years after the original agreement was entered into. The justifications for the acquisition was that land development was proceeding fast enough, as well that the railway should be publicly owned on principal. Many of the farmers who bought into the Midland Railway farmland struggled to make the necessary payments, as the farmland was not of the high quality stated in the company's advertising material. Eventually, the company had to write down the value of the land in the scheme by $40 \%$, in order for the individual farmers to be able to meet their obligations.

The government agreed to pay $£ 1,100,000$ for the tracks and remaining land. The Premier estimated that the company would expect to make approximately $£ 75000$ in revenue that year, of which costs would consume $51 \%$ (p. 934, [62]). This implies a margin of $£ 36,750$, before taxes (and taxes were comparatively low at that time), or a 3.3\% return, if this government offer was considered the market value of the enterprise. This was close to the government interest rate at the time of $3 \%$.

\section{Reinventing Entrepreneurial Infrastructure}

Clark and Moonen [5] note that Australian cities are lagging behind in terms of infrastructure, particularly transport infrastructure, and link this to a relatively undeveloped public transport system. Specifically, they state that "as the metropolitan century unfolds, Australian cities continue to 
attract population growth that surpasses the capacity of their infrastructure systems". The necessary solution is "high-capacity public transport that underpins and supports superb urban amenities with high quality, medium density living", and the authors note that all of the cities that are celebrated today followed this path. Almost all of these cities' railway networks were built by commercially-focused organisations.

In addition to the existing models in Asia, there are emerging examples of development-funded railway building in the cities in North America (Brightline), Europe (Crossrail), and Australia (CLARA) as outlined above. There is also a large body of evidence that railways still raise land values in sprawling, car-dependent cities [32,69-71], suggesting that motorisation is not an insuperable barrier to substantial development-sourced funding.

\subsection{Lessons from Western Australian History}

The Western Australia tramways present a potential case study of how a small but rapidly growing area could fund rail development through real estate. It also suggests a possible regulatory framework for private rail developers, with some of its key features being:

- The requirement for government approval, first through the responsible minister, and then by the legislature.

- Control of building standards and track gauges, to ensure standardisation and integration between the lines of different proponents.

- Prescribed construction timelines and a cash bond, to ensure the promoter delivers the promised infrastructure, and in a timely manner.

- Protections of the rights of adjacent property owners.

- Powers for government agencies to modify or otherwise interfere with the rail infrastructure, if required for some public purpose.

- A strong local government involvement, early on in the process.

Land grant railways demonstrate how publicly-owned land can be used to deliver strategic government objectives, without direct government funding.

As an alternative to granting strategically-located parcels of urban land, long-term leases or the sale of development rights are a common mechanism to retain ultimate government control, while providing land for development. This has been done effectively in Hong Kong (by MTR Corporation); Portland, Oregon (a light rail extension to the airport); and Washington D.C. (Washington Metro's joint development program). The Government of Florida has also begun to offer public land for lease for rail extensions, as noted above.

In addition to a suitable governance model, successful transit infrastructure requires certain conditions to prevail in a city [30]:

- The increment in improved accessibility offered by the new transit.

- The rate of growth, with new transit infrastructure is more likely to affect land development in rapidly growing cities than in those where growth is slower.

- The ease or difficulty in assembling land parcels within close proximity to stations.

- The severity of zoning, or similar political or legal barriers to development.

- Transit-land use integration.

Against the first of these considerations, the improvement in accessibility created by new transit, motorisation and urban sprawl often undermine transit in developed world cities. For example, in contemporary Western Australia, motor vehicle ownership was 863 vehicles per 1000 population [72] almost one vehicle per person. This prevalence of motor vehicles dilutes the accessibility benefits of new transit, however fixed guideway transit still has a measurable effect on land values in car-dependent cities [32]. 
Effectively, all developed countries show high rates of motor vehicle ownership, and there are a range of implicit subsidies to driving. Examples of these implicit subsidies include publicly funded, un-tolled highways, mandatory off-street parking as a development condition and designed to meet peak parking demand [73], land use controls that restrict density and separate land uses, and taxes levied on the existing city being used to fund infrastructure construction in new suburban developments.

The Western Australian case studies support prior findings on the effects of growth in transit provision. The cases presented in this paper are of interest for the small size of the settlements involved suggesting that it is growth in land values that is the core factor in attracting a potential rail project. In addition to growth, urban density is a major determinant for the success of such models. Urban density improves the cost efficiency of rail [74] and its modal share [75]. Estimates have been made of the minimum density required to run viable transit services, although there is some variance in these estimates [76,77]. Zoning will be a critical issue in the success or failure of entrepreneur rail model projects, as there will be a strong link between development yield and project funding.

\subsection{Can City Deals Mimic Historical Rail Governance?}

Historical rail governance models match Newman et al.'s definition of the entrepreneur rail model [1] and raise the question of whether current thinking on PPPs and other policy innovations can be used to mimic these historical models. The obvious candidates to examine are city deals, which are generally delivered as a partnership between different tiers of government, and facilitate greater private sector involvements. There is some justification for public sector support of the entrepreneur rail model, and even in the early days of railway building, government support was not unknown, such as Japan's Light Rail Subsidy Law of 1911, which provided a subsidy of up to 5\% of construction costs (limit later raised), depending on profitability [78].

Such support may be necessary to compensate for the effects of motorisation in undermining efficient transit provision, as discussed above, which has been encouraged by government policy in many countries. It is uncertain whether a completely unsubsidised entrepreneur rail model is possible given the historical automobile urban fabric resulting from the 20th Century period of motorisation and ongoing indirect government support for motorisation.

There are several ways in which a city deal arrangement could support an entrepreneur rail model:

- Demonstration of government commitment: explicit government support can give investors confidence about political and regulatory risk. This is often given as one of the explanations for rail projects' increasing land values.

- Regulatory and compliance burden: one potential role of government is to simplify or otherwise manage its own regulatory approvals processes for a project, including land use planning approvals. In some jurisdictions, approvals can be time-consuming and can create uncertainty. This is a concern raised by the Australian property industry [79].

- Risk: A joint railway and large-scale real estate development is a large project, representing a substantial risk for a private company. In particular, this model requires a large upfront capital for development costs and to build the infrastructure. The returns come later, as the developments go to market, and final sales are uncertain. Government can provide financing guarantees to lower the cost of finance for potentially high-risk undertakings.

- Several roles suggest themselves for different tiers of government in Australian cities:

- Land assembly for redevelopment: this role could be filled by state and local government. In Western Australia, a state government mechanism already exists for acquiring land for long-term strategy infrastructure planning. This is the Metropolitan Region Improvement Fund, which uses revenues from an increment on the state's land tax to fund land voluntary acquisition for public purposes [80]. 
- Concessional finance or underwriting: for large projects, this role might be filled by the national government, whose larger financial resources allow it to better absorb this risk. Concessional finance was provided to the Tsukuba Express project in Japan [81].

- Community and stakeholder engagement: this role can be undertaken by the relevant local governments, and the project proponent, as has been done by the CLARA consortium in Australia.

- Regulatory co-ordination: all tiers of government have regulatory functions. Simplifying this process can result from a partnership between different levels of government. City deals are particularly suited to this function.

City deals are one potential mechanism for government support of an entrepreneurial rail project, and they are currently on the political agenda in Australia. These city deals are predicated on collaboration between the different tiers of government, and "aim to integrate transport, housing and land use policies" [82].

Several agreements have already been signed in Australia, including the Perth City Deal, which is intended to deliver the METRONET railway and transit-oriented development project. The memorandum of understanding covers a wide range of domains of action, but specifies cooperation with local government, communities, and the private sector.

\section{Conclusions}

The early railway building history in Western Australia provides two new case studies of privately-funded railways, integrated with land development. This adds to the body of evidence from Europe, North America, and Asia.

These new case studies are particularly notable for the small population of the settlements involved, combined with their isolation from other major population centres. However, similar to Victorian-era London and the mid-20th Century Japanese cities, rapid population growth and economic development was taking place. This suggests that urban growth, rather than absolute size, is more important for the economics of integrated railway and real estate development.

Similar to the land grant railways in North America, the Western Australian land grant railways are a demonstrated model for partnering with the private sector to achieve government's strategic objectives, particularly when those objectives are beyond the capacity of government to achieve with its own resources. The tramways are another example of urban rail public transport co-developing with and being funded by expanding development.

These provide potential governance/procurement models for increasing private involvement in contemporary cities. The city deal process as suggested by the Australian Federal Government is largely following the governance process created for the original tramway and railway system in Australia and could once again enable a boom in integrated transit, land use, and finance.

However, the historic systems were built prior to motorization, and the question remains as to what extent this would compromise the economics of a similar model in a contemporary city. Numerous recent studies from car dependent cities have shown that land values still respond strongly to railways. The next step is to trial some of the historic models in growing western cities, like Perth, to see if there is potential to accelerate private investment in building urban rail.

Author Contributions: Conceptualization, S.D.-S. and P.N.; Formal analysis, S.D.-S.; Writing-original draft, S.D.-S.; Writing-review \& editing, S.D.-S. and P.N.

Funding: This research was funded by a Ph.D. scholarship from the CRC for Low Carbon Living project number NP2004.

Conflicts of Interest: The authors declare no conflict of interest.

\section{References}

1. Newman, P.; Davies-Slate, S.; Jones, E. The Entrepreneur Rail Model: Funding urban rail through majority private investment in urban regeneration. Res. Transp. Econ. 2016. [CrossRef] 
2. Newman, P.; Kenworthy, J. The End of Automobile Dependence: How Cities Are Moving Beyond Car-Based Planning; Island Press: Washington, DC, USA, 2015.

3. Clark, G.; Clark, G. Nations and the Wealth of Cities: A New Phase in Public Policy; Centre for London: London, UK, 2014.

4. Clark, G.; Moonen, T. Creating Great Australian Cities: Summary Report; Property Council of Australia: Sydney, Australia, 2018.

5. Department of the Prime Minister and the Cabinet. Smart Cities Plan. 2018. Available online: https: / / cities.infrastructure.gov.au/18190/ documents/48080 (accessed on 20 July 2018).

6. Glazebrook, G.; Newman, P. The City of the Future. Urban Plan. 2018, 3, 1-20. [CrossRef]

7. Newman, P.; Glazebrook, G.; Kenworthy, J. Peak car and the rise of global rail: Why this is happening and what it means for large and small cities. J. Transp. Technol. 2013, 3, 272-287. [CrossRef]

8. Renne, J.L. Make Rail (and Transit-Oriented Development) Great Again. Hous. Policy Debate 2017, $27,472-475$. [CrossRef]

9. Scott, Rick. Gov. Scott: FDOT Begins Process for Privately Funded High-Speed Rail from Orlando to Tampa". Media Release; 22 June 2018. Available online: https:/ /www.flgov.com/2018/06/22/gov-scott-fdot-beginsprocess-for-privately-funded-high-speed-rail-from-orlando-to-tampa / (accessed on 20 July 2018).

10. Caisse de Dépôt et Placement du Québec. About Us, Frequently Asked Questions. 2017. Available online: https:/ / www.cdpqinfra.com/en/the-model (accessed on 20 July 2018).

11. Cleary, N.; Consolidated Land and Rail Australia Pty Ltd. Personal communication, 8 June 2018.

12. Crossrail Ltd. Funding. 2018. Available online: http://www.crossrail.co.uk/about-us/funding (accessed on 20 July 2018).

13. Buck, M. Crossrail project: Finance, funding and value capture for London's Elizabeth line. Proc. Inst. Civ. Eng. Civ. Eng. 2017, 170, 15-22. [CrossRef]

14. Regan, M.; Smith, J.; Love, P. Financing of public private partnerships: Transactional evidence from Australian toll roads. Case Stud. Transp. Policy 2017, 5, 267-278. [CrossRef]

15. Goldberg, J. The Brisconnections Airport Link: The Inevitable Collapse of a 5 Billion Dollar Megaproject. In Proceedings of the 35th ARTF Conference, Perth, Australia, 26-28 September 2012.

16. Roukouni, A.; Medda, F. Evaluation of Value Capture Mechanisms as a Funding Source for Urban Transport: The Case of London's Crossrail. Procedia Soc. Behav. Sci. 2012, 48, 2393-2404. [CrossRef]

17. Medda, F.; Cocconcelli, L. To Tax or Not to Tax: The case of London Crossrail. 2013. Available online: https:/ / www.ucl.ac.uk/qaser/pdf/publications/starebei5 (accessed on 20 July 2018).

18. Vadali, S. Value Capture State-of-the Practice Examples (United States): Highways. In Proceedings of the TRB 5th International Summer Finance Conference. 2014. Available online: http://onlinepubs.trb.org/ onlinepubs/conferences /2014/Finance/11.Vadali,Sharada.pdf (accessed on 31 August 2018).

19. SGS Economics and Planning. Innovative Funding Models for Public Transport in Australia; SGS Economics and Planning: Canberra, Australia, 2015.

20. Mathur, S.; Smith, A. A Decision-Support Framework for Using Value Capture to Fund Public Transit: Lessons from Project-Specific Analyses; Faculty Publications, Urban and Regional Planning; San Jose State University: San Jose, CA, USA, 2012; Available online: Scholarworks.sjsu.edu/cgi/viewcontent.cgi?article=1014\&context= urban_plan_pub (accessed on 31 August 2018).

21. Matan, A.; Newman, P. People Cities: The Life and Legacy of Jan Gehl; Island Press: Washington, DC, USA, 2016.

22. City of New York. Business Improvement Districts. 2016. Available online: www1.nyc.gov/site/sbs / neighborhoods/bids.page (accessed on 20 July 2018).

23. Cervero, R. Rail Transit and Joint Development: Land Market Impacts in Washington, D.C. and Atlanta. J. Am. Plan. Assoc. 1994, 60, 83-94. [CrossRef]

24. Cervero, R.; Murakami, J. Rail and Property Development in Hong Kong: Experiences and Extensions. Urban Stud. 2009, 46, 2019-2043. [CrossRef]

25. Mathur, S.; Smith, A. Land value capture to fund public transportation infrastructure: Examination of joint development projects' revenue yield and stability. Transp. Policy 2013, 30, 327-335. [CrossRef]

26. Levinson, D. Density and dispersion: The co-development of land use and rail in London. J. Econ. Geogr. 2008, 8, 55-77. [CrossRef]

27. Perth Airport. Shareholders. 2017. Available online: https://www.perthairport.com.au/Home/corporate/ about-us / corporate-structure/shareholders (accessed on 20 July 2018). 
28. Sharma, R.; Newman, P.; Matan, A. Urban Rail—India's great opportunity for sustainable urban development. In Proceedings of the European Transport Conference, Frankfurt, Germany, 28-30 September 2015.

29. Ubbels, B.; Nijkamp, P.; Verhoef, E.; Potter, S.; Enoch, M. Alternative ways of funding public transport. EJTIR 2001, 1, 73-89. Available online: http://www.ejtir.tudelft.nl/issues/2001_01/pdf/2001_01_05.pdf (accessed on 31 August 2018).

30. Salon, D.; Shewmake, S. Opportunities for Value Capture to Fund Public Transport: A Comprehensive Review of the Literature with a Focus on East Asia; Institute for Transportation and Development Policy: Chennai, India, 2011; Available online: http:/ / papers.ssrn.com/sol3/papers.cfm?abstract_id=1753302 (accessed on 31 August 2018).

31. Rosen, S. Hedonic prices and implicit markets: Product differentiation in pure competition. J. Political Econ. 1974, 82, 601-630. [CrossRef]

32. McIntosh, J.; Trubka, R.; Newman, P. Can Value Capture Work in a Car Dependent City? Willingness to Pay for Transit Access in Perth, Western Australia. Transp. Res. Part A 2014, 67, 320-339. Available online: http:/ / www.sciencedirect.com/science/journal/09658564/67 (accessed on 31 August 2018). [CrossRef]

33. Zhao, Z.; Larson, K. Special assessments as a value capture strategy for public transit finance. Public Works Manag. Policy 2011, 16, 320-340. [CrossRef]

34. Cervero, R. The Transit Metropolis-A Global Inquiry; Island Press: Washington, DC, USA, 1998.

35. Newman, P.W.G.; Kenworthy, J.R. Sustainability and Cities: Overcoming Automobile Dependence; Island Press: Washington, DC, USA, 1999.

36. Newman, P.; Kosonen, L.; Kenworthy, J. Theory of urban fabrics: Planning the walking, transit/public transport and automobile/motor car cities for reduced car dependency. Town Plan. Rev. 2016, 87, 429-458. [CrossRef]

37. Campbell, G.; Turner, J.D. Dispelling the Myth of the Naive Investor during the British Railway Mania, 1845-1846. Bus. Hist. Rev. 2012, 86, 3-41. [CrossRef]

38. Odlyzko, A. The Railway Mania: Fraud, disappointed expectations, and the modern economy. J. Railway Canal Hist. Soc. 2012, 215, 1-16.

39. Odlyzko, A. The forgotten discovery of gravity models and the inefficiency of early railway networks. OEconomia 2015, 5, 157-192. [CrossRef]

40. Wolmar, C. The Subterranean Railway: How the London Underground Was Built and How It Changed the City Forever; Atlantic Books: London, UK, 2004.

41. Harter, J. World Railways of the Nineteenth Century: A Pictorial History in Victorian Engravings; JHU Press: Baltimore, MD, USA, 2005; p. 52.

42. Warner, S.B., Jr. Streetcar Suburbs, The Process of Growth in Boston, 1870-1900; Colonial Society of Massachusetts and the New England Quarterly, etc. 36: 397; Harvard University Press; MIT Press: Cambridge, MA, USA, 1963.

43. Canadian Pacific (Undated) Our History. Available online: https:/ / cpconnectingcanada.ca/our-history / (accessed on 20 July 2018).

44. Canadian Pacific (Undated) Immigration and Settlement. Available online: https://cpconnectingcanada.ca / \#immigration-settlements (accessed on 20 July 2018).

45. Hanna, J. Colonist Cars Helped Build the West. Momentum, Fall. 2008. Available online: http://www. okthepk.ca/dataCprSiding/cprNews / cpNews90/08090100.html (accessed on 20 July 2018).

46. Canadian Pacific. Real Estate Opportunities. 2018. Available online: http://www.cpr.ca/en/about-cp/realestate (accessed on 20 July 2018).

47. MTR Corporation. FAQ, 2. What Is the Company's Relationship with the Hong Kong SAR Government? 2014. Available online: https://www.mtr.com.hk/en/corporate/investor/investor_faq.html\#02 (accessed on 20 July 2018).

48. MTR Corporation. Operating Profit Contributions. 2018. Available online: http://www.mtr.com.hk/ archive/corporate/en/investor/profit_en.pdf (accessed on 20 July 2018).

49. Government of Singapore. 6 Things You Need to Know about the New Rail Financing Framework. 2018. Available online: https: / www.gov.sg/factually / content/ 6-things-you-need-to-know-about-the-new-railfinancing-framework (accessed on 20 July 2018).

50. Land Transport Authority. Train Operators. 2015. Available online: https://www.lta.gov.sg/content/ ltaweb/en/public-transport/mrt-and-lrt-trains/train-operators.html (accessed on 20 July 2018). 
51. Land Transport Authority (Singapore). Bus Industry to Complete Transition to Bus Contracting Model on 1 September 2016. News Release; 11 August 2016. Available online: https:/ /www.lta.gov.sg/apps/news / page.aspx?c=2\&id=e1fbdb6d-3200-4b23-846e-bb2184ba3dcc (accessed on 20 July 2018).

52. Temasek. Temasek Review 2017: Transportation \& Industrials. 2017. Available online: http://www. temasekreview.com.sg/major-investments/transportation-and-industrials.html. (accessed on 20 July 2018).

53. Land Transport Authority. About LTA. 2017. Available online: https://www.lta.gov.sg/content/ltaweb/en/ about-lta.html (accessed on 20 July 2018).

54. Cervero, R.; Murakami, J. Rail + Property Development: A Model of Sustainable Transit Finance and Urbanism; Working Paper; UC Berkeley Center for Future Urban Transport: Berkeley, CA, USA, 2008; p. 141.

55. Department of Infrastructure and Regional Development (Australia). History of Rail in Australia; Department of Infrastructure and Regional Development: Canberra, Australia, 2017. Available online: https:// infrastructure.gov.au/rail/trains/history.aspx (accessed on 20 July 2018).

56. Public Transport Authority of Western Australia. Our History-1830 to 1900; Public Transport Authority of Western Australia: Perth, Australia, 2017. Available online: http:/ /www.pta.wa.gov.au/about-us/our-role/ our-history\#1830-to-1900-28 (accessed on 20 July 2018).

57. Culpeffer-Cooke, T.; Gunzburg, A.; Pleydell, I.; Brown, D. (Eds.) Tracks by the Swan: The Electric Tram and Trolley Bus Era of Perth, Western Australia; Perth Electric Tramway Society Inc.: Mount Lawley, Australia, 2010.

58. Australian Bureau of Statistics. Australian Historical Population Statistics. Catalogue Number 3105.0.65.001, Table 3. 2014. Available online: http://www.abs.gov.au/AUSSTATS/abs@.nsf/DetailsPage/3105.0.65. 0012014? OpenDocument (accessed on 31 August 2018).

59. Government of the Western Australia. Tramways Act (Western Australia). 1885. Available online: https: / / www.legislation.wa.gov.au/legislation/statutes.nsf/law_a2958.html (accessed on 31 August 2018).

60. Legislative Assembly (Western Australia). Parliamentary Debates; 23 September 1885, 385. Hon. J.A. Wright, Engineer-in-Chief. 1885. Available online: http:/ / www.parliament.wa.gov.au/hansard/hansard1870to1995. nsf/vwWeb1880Main?OpenView\&Start=1\&Count=1000\&Expand=6\#6 (accessed on 31 August 2018).

61. Battye Library. Enlargement of Nedlands Park Tramway Estate Booklet, Published 1908; Battye Library: Perth, Australia, 1975.

62. Legislative Assembly (Western Australia). Parliamentary Debates. 1907. Available online: http:/ / www.parliament.wa.gov.au/hansard/hansard1870to1995.nsf/vwWeb1900Main?OpenView\& Start $=1 \&$ Count $=1000 \&$ Expand $=8 \# 8$ (accessed on 31 August 2018).

63. Government of the Western Australia. Nedlands Park Tramway Act (Western Australia). 1907. Available online: https:/ / www.legislation.wa.gov.au/legislation/statutes.nsf/main_mrtitle_9526_homepage.html (accessed on 31 August 2018).

64. Pellatt, S.H. Osborne Park; Dix and Little: Perth, Australia, 1913.

65. Easton, L.A. Stirling City; University of Western Australia Press: Perth, Australia, 1972.

66. Government of the Western Australia. North Perth and Perth Road Board Districts Tramways Act (Western Australia). 1902. Available online: https://www.legislation.wa.gov.au/legislation/prod/filestore.nsf/ FileURL/mrdoc_14128.pdf/\$FILE/North\%20Perth\%20and\%20Perth\%20Road\%20Board\%20Districts\% 20Tramways\%20Act\%201902\%20-\%20\%5B00-00-00\%5D.pdf?OpenElement (accessed on 31 August 2018).

67. State Library of Western Australia. J S Battye Library of West Australian History Midland Railway Company. Private Archives-Collection Listing; M/N 0239/1, Acc. 1557A, 1558A; State Library of Western Australia: Perth, Australia, 2002.

68. Legislative Assembly (Western Australia). Parliamentary Debates. 1896. Available online: http:/ / www.parliament.wa.gov.au/hansard/hansard1870to1995.nsf/vwWeb1890Main?OpenView\& Start=1\&Count=1000\&Expand=7\#7 (accessed on 31 August 2018).

69. Gatzlaff, D.H.; Smith, M.T. The impact of the Miami Metrorail on the value of residences near station locations. Land Econ. 1993, 69, 54-66. [CrossRef]

70. Cervero, R. Effects of Light and Commuter Rail Transit on Land Prices: Experiences in San Diego County. J. Transp. Res. Forum 2004, 43, 121-138. [CrossRef]

71. Du, H.; Mulley, C. Transport Accessibility and Land Values: A Case Study of Tyne and Wear. Rep. RICS Res. Pap. Ser. 2007, 7, 1-52. 
72. Australian Bureau of Statistics. Motor Vehicle Census, Australia, 31 January 2018. Catalogue Number 9309.0, Table 2. 2018. Available online: http://www.abs.gov.au/AUSSTATS/abs@.nsf/DetailsPage/9309.031\% 20Jan\%202018?OpenDocument (accessed on 31 August 2018).

73. Shoup, D. The High Cost of Free Parking. J. Plan. Educ. Res. 1997, 17, 3-20. [CrossRef]

74. Guerra, E.; Cervero, R. Cost of a ride: The effects of densities on fixed-guideway transit ridership and costs. J. Am. Plan. Assoc. 2011, 77, 267-290. [CrossRef]

75. Frank, L.; Pivo, G. The Impacts of Mixed Use and Density on the Utilization of Three Modes of Travel: The Single Occupant Vehicle, Transit, and Walking. Transp. Res. Rec. 1994, 1466, 44-52.

76. Pushkarev, B.; Zupan, J. Public Transportation and Land Use Policy; Indiana University Press: Bloomington, IN, USA, 1977.

77. Dittmar, H.; Ohland, G. The New Transit Town: Best Practices in Transit-Oriented Development; Island Press: Washington, DC, USA, 2004.

78. Hirooka, H. The development of Tokyo's rail network. Jpn. Railw. Transp. Rev. 2000, 23, 22-30.

79. Property Council of Australia (Undated) Less Red Tape. Available online: https://www.propertycouncil. com.au/Web/Advocacy/Advocacy_Priorities/Red_tape/Web/Advocacy/Priority/Red_Tape.aspx? hkey=8c2ac5d1-3f23-4d5a-b9c6-0182723945cf (accessed on 20 July 2018).

80. Office of State Revenue (Western Australia) (Undated) 2014-15 Land Tax. Available online: https:/ / www. finance.wa.gov.au/cms/uploadedFiles/_State_Revenue/Land_Tax/Land_Tax_Brochure_2014-15.pdf (accessed on 20 July 2018).

81. Metropolitan Intercity Railway Company. Metropolitan Intercity Railway Company (undated) Company Profile; Metropolitan Intercity Railway Company: Tokyo, Japan, 2018.

82. Department of the Prime Minister and Cabinet (Australia) (Undated) Delivering City Deals. Available online: https:/ / cities.infrastructure.gov.au/19047/documents/64949 (accessed on 10 August 2018).

(C) 2018 by the authors. Licensee MDPI, Basel, Switzerland. This article is an open access article distributed under the terms and conditions of the Creative Commons Attribution (CC BY) license (http:/ / creativecommons.org/licenses/by/4.0/). 